\title{
Investigation of Ferrochromium Wastes for their Hazardous Hexavalent Chromium Content
}

\author{
İlker Acar ${ }^{1 *}$

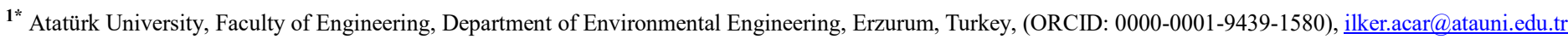

(First received 15 June 2021 and in final form 21 August 2021)

(DOI: 10.31590 /ejosat.952386)

ATIF/REFERENCE: Acar, İ. (2021). Investigation of Ferrochromium Wastes for their Hazardous Hexavalent Chromium Content. European Journal of Science and Technology, (27), 204-209.

\begin{abstract}
In this study, ferrochromium slag (FS) and electric-arc furnace dust (EAFD) samples were examined for their hazardous hexavalent chromium content mainly by X-ray photoelectron spectroscopy (XPS) analysis. According to the experimental results, magnesiumsilicate constitutes the main framework of both FS and EAFD samples. Highly crystalline FS contains $3.11 \% \mathrm{Cr}_{2} \mathrm{O}_{3}$ as spinel phases while this constituent is much higher, $15.44 \%$, in EAFD. The general XPS spectra show that both samples mainly consist of O, Mg and Si elements. In addition, FS also includes aluminum while carbon, calcium and potassium are the other major elements for EAFD. The peaks appeared in the range of 577-589 eV confirm chromium content of the samples. Besides, the peaks appeared at 1022 and 1045 eV point out zinc content of EAFD. Based on the XPS atomic ratio, Cr contents of FS and EAFD were obtained as 0.505 and $0.987 \%$, respectively while EAFD further contains $2.594 \% \mathrm{Zn}$. The detailed XPS analysis indicates that chromium exists as two oxidation states, trivalent and hexavalent forms at $2 p$ orbitals. Specifically, for $2 p_{3 / 2}$ orbitals, trivalent and hexavalent chromium were assigned at 577.1 and $579.2 \mathrm{eV}$, respectively whereas 586.9 and $588.9 \mathrm{eV}$ for $2 \mathrm{p}_{1 / 2}$ orbitals. Furthermore, the corresponding intensities of these peaks are much higher for EAFD. By comparing the peak intensities, the relative proportions of Cr (VI) were calculated as 49.44 and $49.53 \%$ for FS and EAFD, respectively. The leaching tests show that solubilities of all the metals examined except $\mathrm{Cr}$ are far below the toxicity limits for hazardous waste and even below the ranges of non-hazardous waste. Specifically, chromium contents of the filtrates were determined as 0.862 and $268.050 \mathrm{mg} / \mathrm{l}$ for FS and EAFD, respectively. Considering the toxicity limits of chromium, EAFD can be surely labeled as a highly hazardous waste whereas, on the other hand, FS is within the limits of non-hazardous waste. In conclusion, it can be said that the hazardous hexavalent chromium content must be reduced to immobile trivalent forms for the dust sample prior to disposed in landfills.
\end{abstract}

Keywords: Hexavalent chromium, Ferrochromium slag, Electric-arc furnace dust, Hazardous waste, XPS.

\section{Ferrokrom Atıklarının Tehlikeli Altı Değerlikli Krom İçeriği Açısından İncelenmesi}

$\ddot{O} \mathbf{z}$

Bu çalışmada, ferrokrom cürufu (FS) ve elektrik-ark firını tozu (EAFD) numuneleri esas olarak X-1şını fotoelektron spektroskopi (XPS) analizi ile tehlikeli altı değerlikli krom içerikleri açısından incelenmiştir. Deneysel sonuçlara göre, magnezyum-silikat, hem FS hem de EAFD numunelerinin ana çerçevesini oluşturmaktadır. Yüksek kristalli FS, spinel fazlar olarak \%3, $11 \mathrm{Cr}_{2} \mathrm{O}_{3}$ içerirken, bu bileşen EAFD içerisinde çok daha yüksektir $(\% 15,44)$. Genel XPS spektrumları, her iki numunenin de esas olarak O, Mg ve Si elementlerinden oluştuğunu göstermektedir. Ek olarak, FS ayrıca alüminyum içerirken, karbon, kalsiyum ve potasyum EAFD için diğer ana elementlerdir. 577-589 eV aralığında görünen pikler, numunelerin krom içeriğini doğrulamaktadır. Ayrıca, 1022 ve 1045 eV'de ortaya çıkan pikler, EAFD'nin çinko içeriğine işaret etmektedir. XPS atom oranına göre, FS ve EAFD'nin Cr içerikleri sırasıyla \%0,505 ve $\% 0,987$ olarak elde edilirken, EAFD ayrıca \%2,594 Zn içerir. Ayrıntılı XPS analizi, kromun 2p orbitallerinde üç değerlikli ve altı değerlikli formlar olmak üzere iki oksidasyon durumunda bulunduğunu göstermektedir. Spesifik olarak, $2 \mathrm{p}_{3 / 2}$ orbitalleri için üç değerlikli ve altı değerlikli krom sırasıyla 577,1 ve 579,2 eV'de, 2p p1/2 orbitalleri için ise 586,9 ve 588,9 eV'de belirlenmiştir. Ayrıca, bu piklerin karşılık gelen şiddetleri EAFD için çok daha yüksektir. Pik şiddetleri karşılaştırılarak, Cr (VI) nispi oranları FS ve EAFD için sırasıyla \%49,44 ve \%49,53 olarak hesaplanmıştır. Liç testleri, Cr hariç incelenen tüm metallerin çözünürlüklerinin, tehlikeli atık toksisite sınırlarının çok altında ve hatta tehlikeli olmayan atık aralıklarının dahi altında olduğunu göstermektedir. Spesifik olarak, filtratların krom içerikleri FS ve EAFD için sırasıyla 0,862 ve 268,050 mg/l olarak belirlenmiştir. Kromun toksisite limitleri göz önüne alındığında, EAFD kesinlikle çok tehlikeli bir atık olarak etiketlenebilirken, FS ise tehlikesiz atık sınırları içindedir. Sonuç olarak,

* Corresponding Author: ilker.acar@atauni.edu.tr 
özellikle toz numunesi için, tehlikeli altı değerlikli krom içeriğinin düzenli depolama sahalarına atılmadan önce durağan üç değerlikli formlara indirgenmesi gerektiği söylenebilir.

Anahtar Kelimeler: Altı değerlikli krom, Ferrokrom cürufu, Elektrik-ark firını tozu, Tehlikeli atık, XPS.

\section{Introduction}

Ferrochromium consisting mainly of chromium, iron and carbon is one of the most widely used alloy for the manufacturing of stainless steel. The two by-products resulted from the ferrochrome production are ferrochromium slag (FS) and electricarc furnace dust (EAFD) (Aigbe and Osibote, 2020; Bulut et al., 2009; Erdem et al., 2005; Jena and Panigrahi, 2021).

The main bulk waste, FS is generated from the successive carbothermal process in electric-arc furnaces and mostly forms as a dense rock with high degree of crystallinity due to the slow cooling in the air (Gencel et al., 2013; Sekhar Biswal et al., 2021). Depending on the mineralogy and chemistry of feed materials, approximately 1.1-1.6 tons FS is resulted for a ton of ferrochrome produced. Accordingly, the annual production of FS is estimated around 12.5 million tons with the increasing rate of $2.8-3.0 \%$ by weight in every year (Nath, 2018). A small percentage of this finds applications in construction industry as mostly aggregate but the vast majority is held in dumps (Bulut et al., 2009; Gencel et al., 2013; Nath, 2018). However, this can be regarded as environmentally undesirable approach due to its high levels toxic elements (Bulut et al., 2009; Sohel et al., 2021; Panda et al., 2013).

EAFD, on the other hand, is generated by the subsequent volatilization, oxidation and solidification of metals such as $\mathrm{Zn}$, $\mathrm{Pb}, \mathrm{Cd}, \mathrm{Ni}$, and $\mathrm{Cr}$ in the form of a dust (Arnold et al., 2017). In contrast to FS, only 10-20 kg EAFD is resulted per a ton of ferrochrome produced. Approximately $30 \%$ of EAFD finds application as source materials for the recovery of metals, while the remaining $70 \%$ is disposed in landfills (Arnold et al., 2017; Bulut et al., 2009; Cholake et al., 2018). EAFD also contains high levels of extractable toxic elements such as $\mathrm{Cr}, \mathrm{Zn}, \mathrm{Pb}, \mathrm{Ni}$ and $\mathrm{Cd}$, and has been categorized as hazardous waste due to its chemical, physical and leachability properties. Accordingly, its disposing in landfills without any pre-treatments such as detoxification and immobilization processes is strongly prohibited by a wide range of countries (Bulut et al., 2009; Fernández Pereira et al., 2009; Shahid et al., 2017).

One of the most hazardous elements present in both FS and EAFD is chromium, particularly its hexavalent state. Despite its several oxidation states, the two most common and stable forms are hexavalent and trivalent chromium. Unlike trivalent chromite, hexavalent chromate has a potential health hazard mainly due to its high mobility, extreme toxicity and carcinogenic property. Therefore, the main detoxification mechanism is based on the reduction of hazardous hexavalent chromate to its immobile trivalent chromite form (Bulut et al., 2009; Chagas et al., 2019; Dhal et al., 2013; Fares et al., 2021; Fernández Pereira et al., 2009; Panda et al., 2013; Shahid et al., 2017).

In this study, a slag and an electric-arc furnace dust resulted from a ferrochrome production process were examined for their hexavalent chromium content mainly by X-ray photoelectron spectroscopy (XPS) analysis.

\section{Material and Method}

\subsection{Materials}

The ferrochrome slag (FS) and electric-arc furnace dust (EAFD) samples used were resulted from the ferrochrome production plant of ETI KROM INC. located in Kovancilar, Elazığ, Turkey. In this plant, after the removal of ferrochromium metal from the slag in liquid state, the molten slag is slowly cooled in air. This results in a highly crystalline irregularly-shaped lumpy material with approximately $4-5 \mathrm{~cm}$ in size (Erdoğan, 2011; Gencel et al., 2013; Nath, 2018). Therefore, prior to the instrumental analyses, FS sample was crushed and ground to particle size finer than $100 \mu \mathrm{m}$.

\subsection{Methods}

\subsubsection{Characterization of the Materials}

The main oxide composition was determined by a Spectro IQ $\mathrm{X}$-ray fluorescence analyzer. The particle size distribution of EAFD was measured with wet-sieving analysis using Tyler sieve series from $425 \mu \mathrm{m}$ down to $38 \mu \mathrm{m}$. The major crystalline inclusions of the samples were examined by a PANalytical Empyrean X-ray diffractometer (XRD) operating with $\mathrm{Cu}-\mathrm{Ka}$ radiation $(\lambda=1.54060 \AA)$ at $40 \mathrm{kV}$ and $40 \mathrm{~mA}$ over $10-70^{\circ}$. Thermogravimetric analyses were carried out with a TGA 1500 instrument in nitrogen atmosphere.

\subsubsection{XPS Analysis}

XPS analysis can be considered as an accurate method used to determine oxidation state of transition metals (Greunz et al., 2018). Therefore, in this study, XPS analysis was conducted by a Specs-Flex instrument for the determination of hexavalent chromium contents of FS and EAFD samples. General survey spectra were recorded for the binding energy of $0-1387 \mathrm{eV}$ at 100 $\mathrm{eV}$ pass energy while narrow range spectra for chromium element were acquired in the range of 564-604 eV at the pass energy of 40 $\mathrm{eV}$.

\subsubsection{Leaching Test}

Leachability characteristics of FS and EAFD samples were examined for eight elements in accordance with TS EN 12457-4 leaching test (Acar and Atalay, 2013). Heavy metal contents of the filtrates were determined by an Agilent 7800 inductively coupled plasma-mass spectroscopy. The regulation of hazardous waste in Turkish standard (Appendix 11-A) was used to evaluate the obtained heavy metal contents for their toxicity limits (Acar and Atalay, 2013).

\section{Results and Discussion}

\subsection{The Results of Material Characterization}

The major oxide compositions of the samples are given in Table 1 .

Table 1 The main chemical compositions of FS and EAFD

\begin{tabular}{l|c|c}
\hline Constituents (\%) & FS & EAFD \\
\hline $\mathrm{MgO}$ & 38.31 & 15.13 \\
\hline $\mathrm{SiO}_{2}$ & 32.56 & 18.88 \\
\hline $\mathrm{Al}_{2} \mathrm{O}_{3}$ & 23.01 & 3.65 \\
\hline $\mathrm{Cr}_{2} \mathrm{O}_{3}$ & 3.11 & 15.44 \\
\hline $\mathrm{Fe}_{2} \mathrm{O}_{3}$ & 1.29 & 7.37 \\
\hline $\mathrm{CaO}$ & 1.22 & 6.26 \\
\hline
\end{tabular}


According to Table $1, \mathrm{MgO}, \mathrm{SiO}_{2}$ and $\mathrm{Al}_{2} \mathrm{O}_{3}$ constitute the main chemical composition of FS which also includes $3.11 \%$ $\mathrm{Cr}_{2} \mathrm{O}_{3}$ and very low amounts of $\mathrm{Fe}_{2} \mathrm{O}_{3}$ and $\mathrm{CaO}$ contents. Similar chemical compositions with varying $\mathrm{Cr}_{2} \mathrm{O}_{3}$ contents were also reported in the literature (Erdoğan, 2011; Gencel et al., 2013; Jena and Panigrahi, 2021). On the other hand, EAFD contains much higher $\mathrm{Cr}_{2} \mathrm{O}_{3}$ content, $15.44 \%$, and lower $\mathrm{SiO}_{2}, \mathrm{MgO}$ and $\mathrm{Al}_{2} \mathrm{O}_{3}$ contents with respect to $\mathrm{FS}$, all of which are correlated with the literature investigations (Bulut et al., 2009; Kumar B et al., 2020; Mishra et al., 2020).

The particle size distribution of EAFD sample is given in Figure 1. As seen in Figure 1, almost all of the particles pass through $425 \mu \mathrm{m}$ while $80 \%\left(\mathrm{P}_{80}\right)$ and $50 \%\left(\mathrm{P}_{50}\right)$ cumulative passing sizes by weight were determined to be approximately 143 $\mu \mathrm{m}$ and $79 \mu \mathrm{m}$, respectively. Similar particle size distribution was also reported in the literature (Bulut et al., 2009).

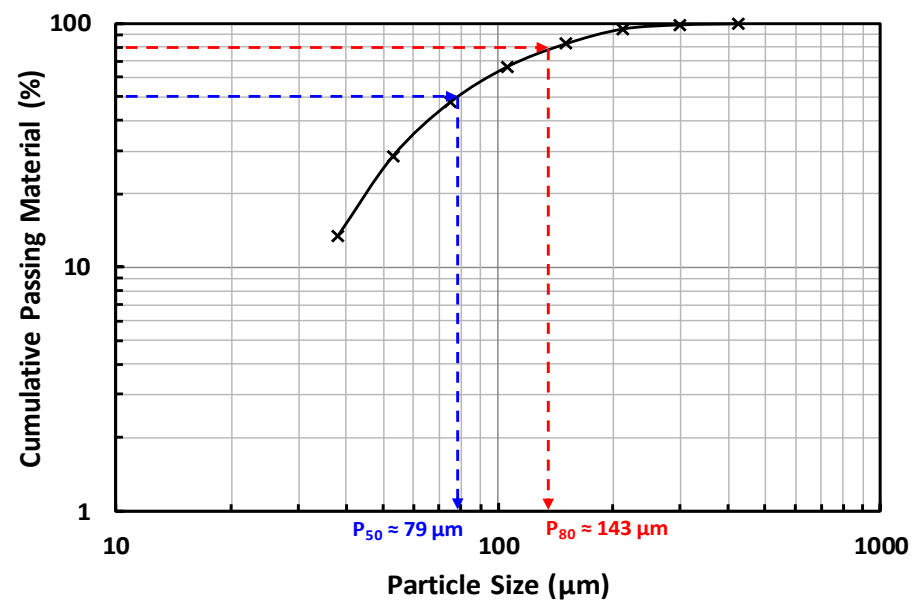

Figure 1 The particle size distribution of EAFD

The XRD pattern of FS and EAFD samples are illustrated in Figure 2. As seen in Figure 2-(a), FS sample mainly consists of magnesium-silicate and magnesium-aluminate minerals. In addition, it exhibits high crystallinity probably due to the slow air cooling. Specifically, forsterite $\left((\mathrm{Mg}, \mathrm{Fe})_{2} \mathrm{SiO}_{4}\right), \mathrm{Fe}-\mathrm{Mg}-\mathrm{Cr}-\mathrm{Al}-$ spinels $\left(\mathrm{MgAl}_{2} \mathrm{O}_{4}\right)$ and enstatite $\left(\mathrm{MgSiO}_{3}\right)$ phases were determined from the XRD analysis. The results obtained are well correlated with the literature studies (Acar, 2020; Erdoğan, 2011; Gencel et al., 2013; Nath, 2018).

On the other hand, Figure 2-(b) indicates that the main crystalline inclusions of EAFD were determined as forsterite $\left(\mathrm{Mg}_{2} \mathrm{SiO}_{4}\right)$ and cristobalite low $\left(\mathrm{SiO}_{2}\right)$, and also includes magnesium dichromium oxide $\left(\mathrm{Cr}_{2} \mathrm{MgO}_{4}\right)$, calcium silicide (CaSi), magnesium silicide $\left(\mathrm{Mg}_{2} \mathrm{Si}\right)$, fayalite $\left(\mathrm{Fe}_{2} \mathrm{SiO}_{4}\right)$ and stishovite $\left(\mathrm{SiO}_{2}\right)$. Parallel crystalline phases were also reported in the literature (Mishra et al., 2020).

According to the thermogravimetric analyses conducted, FS exhibited almost no weight reduction, only $0.065 \%$ up to the highest temperature tested (Gencel et al., 2013). On the other hand, EAFD showed $8.22 \%$ weight reduction probably due to its unburn coke inclusion. High loss on ignition of electric-arc furnace dust was also reported in the literature (Fernández Pereira et al., 2009).
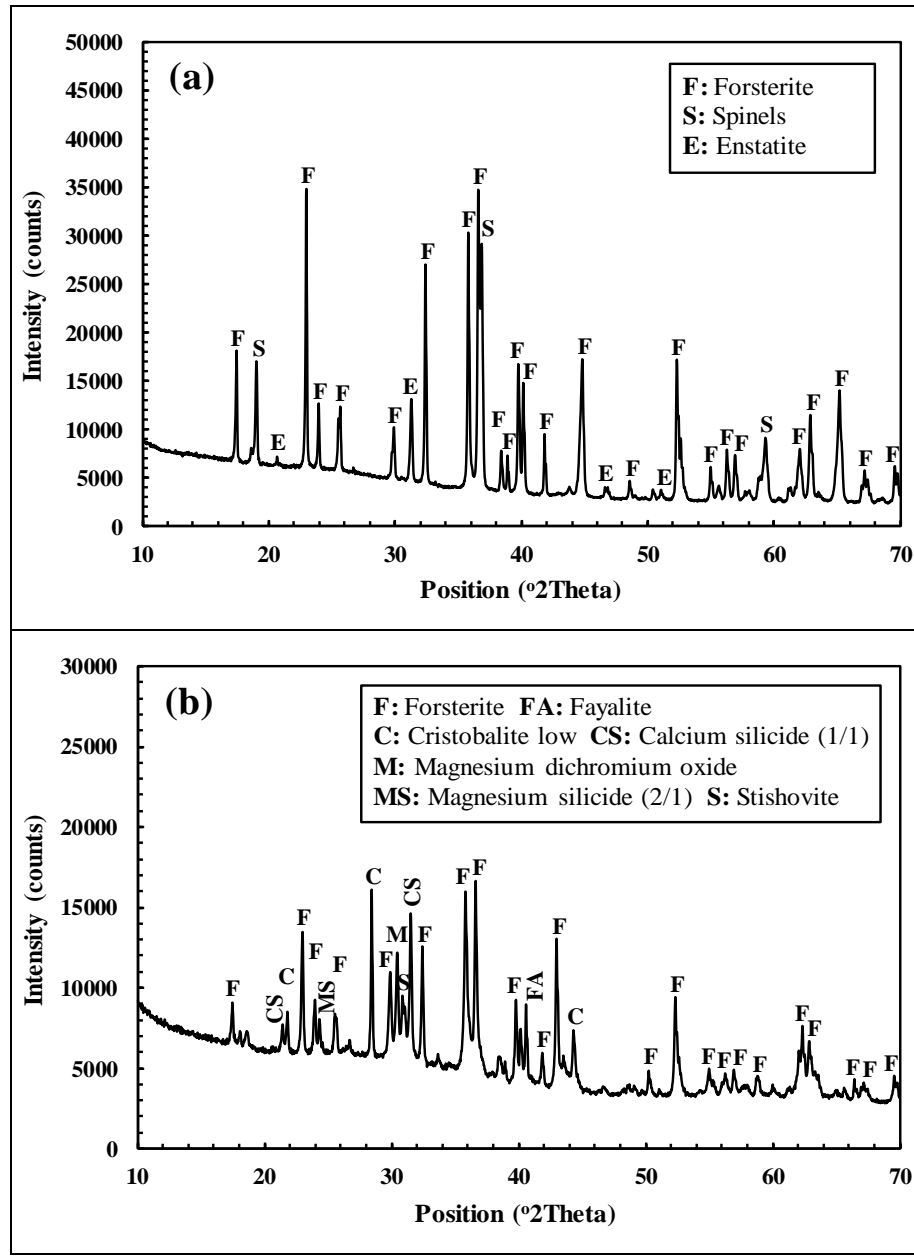

Figure 2 Mineralogical compositions of FS (a) and EAFD (b)

\subsection{The Results of XPS Measurements}

Figure 3 displays the general XPS spectra of FS and EAFD samples. As seen in Figure 3-(a), the peaks of $\mathrm{O}, \mathrm{Mg}, \mathrm{Si}, \mathrm{Al}$ and $\mathrm{Ca}$ elements were mainly determined for FS. In addition, low intensity peaks appeared at 575 and $588 \mathrm{eV}$ confirm chromium inclusion of FS sample.

Similarly, the peaks of $\mathrm{O}, \mathrm{Mg}, \mathrm{Si}$ and $\mathrm{Ca}$ elements except $\mathrm{Al}$ can be clearly seen for EAFD in Figure 3-(b). Different to FS, the general XPS spectra of EAFD also includes the peaks of $\mathrm{K}, \mathrm{Na}$, $\mathrm{Cl}$ and $\mathrm{S}$ elements probably resulted from burning of coke. Moreover, higher intensity peaks at 577 and $588 \mathrm{eV}$ with respect to FS confirm the higher chromium content of EAFD sample. In addition to chromium, another heavy metal element, zinc was also determined from the peaks appeared at 1022 and $1045 \mathrm{eV}$.

XPS atomic ratios of FS and EAFD samples are given in Tables 2 and 3, respectively. According to Table 2, consistent with the XRF results, $\mathrm{O}, \mathrm{Mg}, \mathrm{Si}$ and $\mathrm{Al}$ constitute the main elemental composition of FS sample. Inconsistent $\mathrm{Ca}$ and $\mathrm{C}$ contents with regard to the XRF and TGA results can be attributed to the peak overlaps among $\mathrm{Ca}, \mathrm{C}$ and $\mathrm{Mg}$.

Table 3 indicates that the major elements detected for EAFD sample are $\mathrm{O}, \mathrm{Mg}, \mathrm{Si}, \mathrm{C}, \mathrm{Ca}$ and $\mathrm{K}$. In addition, EAFD also has a high $\mathrm{Zn}$ content, $2.594 \%$, and about two times higher $\mathrm{Cr}$ content, $0.987 \%$, with respect to FS sample. 

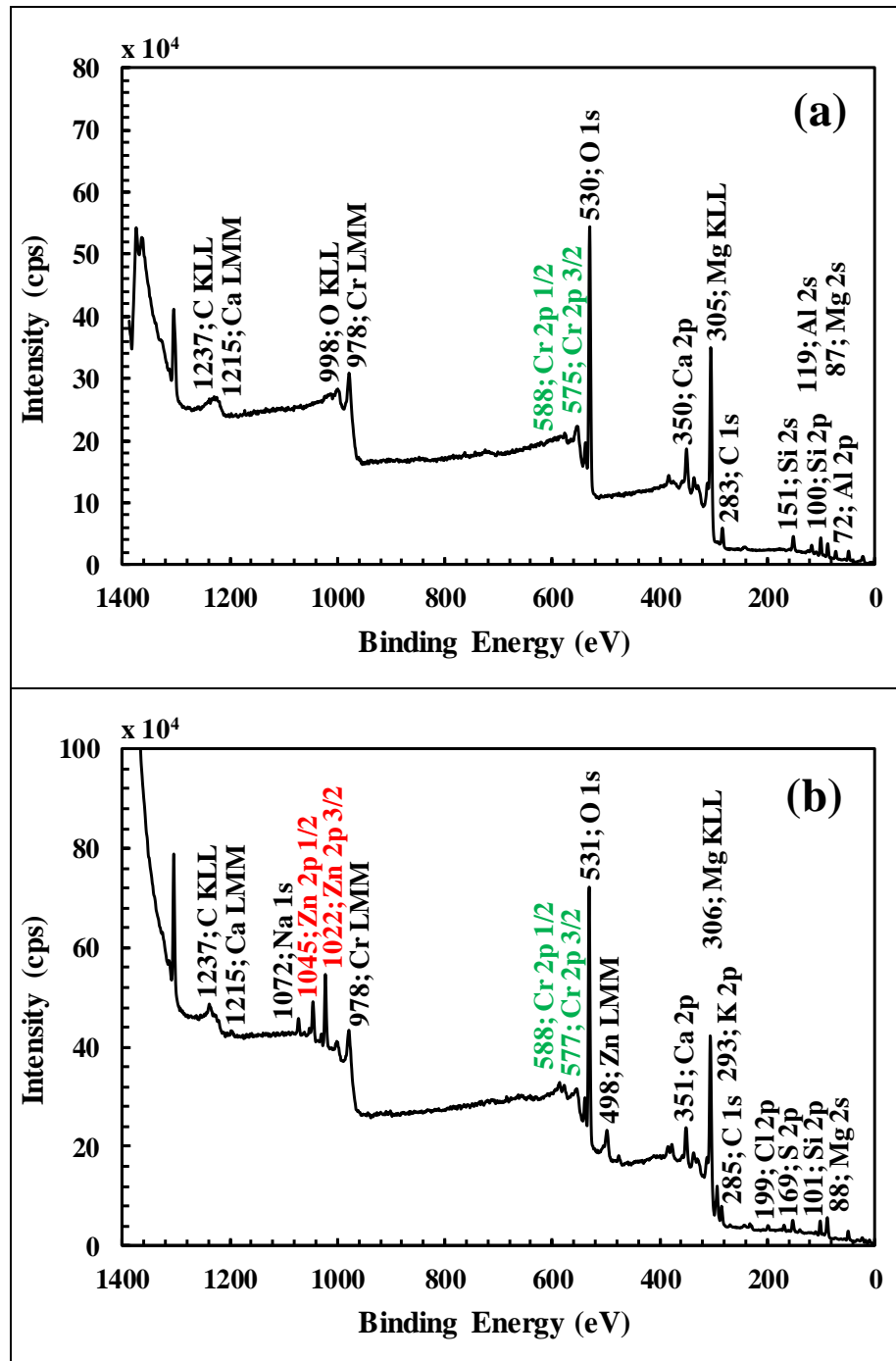

Figure 3 General XPS spectra of FS (a) and EAFD (b)

Table 2 XPS atomic ratio of FS

\begin{tabular}{l|c|c|c}
\hline Elements & Orbitals & $\begin{array}{c}\text { Positions } \\
(\mathbf{e V})\end{array}$ & $\begin{array}{c}\text { Atomic ratio } \\
(\mathbf{\%})\end{array}$ \\
\hline$O$ & $1 \mathrm{~s}$ & 530 & 56.200 \\
\hline$M g$ & $2 \mathrm{~s}$ & 87 & 10.888 \\
\hline $\mathrm{Si}$ & $2 \mathrm{p}$ & 100 & 9.212 \\
\hline $\mathrm{Al}$ & $2 \mathrm{p}$ & 72 & 5.595 \\
\hline $\mathrm{Ca}$ & $2 \mathrm{p}$ & 350 & 7.321 \\
\hline $\mathrm{Cr}$ & $\mathbf{2 p ~ 3 / 2}$ & $\mathbf{5 7 5}$ & $\mathbf{0 . 5 0 5}$ \\
\hline $\mathrm{C}$ & $1 \mathrm{~s}$ & 283 & 10.142 \\
\hline
\end{tabular}

Figure 4 illustrates the detailed narrow range spectra of FS and EAFD for chromium. As seen in Figure 4, two oxidation states, trivalent and hexavalent chromium were determined at $2 \mathrm{p}_{3 / 2}$ and $2 \mathrm{p}_{1 / 2}$ orbitals. According to the literature investigations, for $\mathrm{Cr} 2 \mathrm{p}_{3 / 2}$ orbitals, trivalent chromium forms of $\mathrm{Cr}_{2} \mathrm{O}_{3}$ and $\mathrm{CrCl}_{3}$ are characterized with the peaks appeared at 576.2-576.5 and $577.2 \mathrm{eV}$, respectively. On the other hand, hexavalent chromium forms of $\mathrm{CrO}_{3}$ and $\mathrm{K}_{2} \mathrm{Cr}_{2} \mathrm{O}_{7}$ correspond to higher binding energies, 578.1 and $579.2 \mathrm{eV}$, respectively. For $\mathrm{Cr} 2 \mathrm{p}_{1 / 2}$ orbitals, trivalent and hexavalent chromium forms are sequentially attributed to the binding energy ranges of 586.66-586.98 and 588.77-589.68 eV (Greunz et al., 2018; Murphy et al., 2009).

Table 3 XPS atomic ratio of EAFD

\begin{tabular}{l|c|c|c}
\hline Elements & Orbitals & $\begin{array}{c}\text { Positions } \\
(\mathbf{e V})\end{array}$ & $\begin{array}{c}\text { Atomic ratio } \\
(\mathbf{\%})\end{array}$ \\
\hline$O$ & $1 \mathrm{~s}$ & 531 & 49.953 \\
\hline$M g$ & $2 \mathrm{~s}$ & 88 & 17.115 \\
\hline$S i$ & $2 \mathrm{p}$ & 101 & 7.236 \\
\hline$S$ & $2 \mathrm{p}$ & 169 & 1.624 \\
\hline$C l$ & $2 \mathrm{p}$ & 199 & 1.015 \\
\hline$C a$ & $2 \mathrm{p}$ & 351 & 5.965 \\
\hline$N a$ & $1 \mathrm{~s}$ & 1072 & 1.369 \\
\hline$K$ & $2 \mathrm{p}$ & 293 & 4.276 \\
\hline $\boldsymbol{C r}$ & $\mathbf{2 p ~ 3 / 2}$ & $\mathbf{5 7 7}$ & $\mathbf{0 . 9 8 7}$ \\
\hline $\boldsymbol{Z n}$ & $\mathbf{2 p ~ 3 / 2}$ & $\mathbf{1 0 2 2}$ & $\mathbf{2 . 5 9 4}$ \\
\hline$C$ & $1 \mathrm{~s}$ & 285 & 7.865 \\
\hline
\end{tabular}
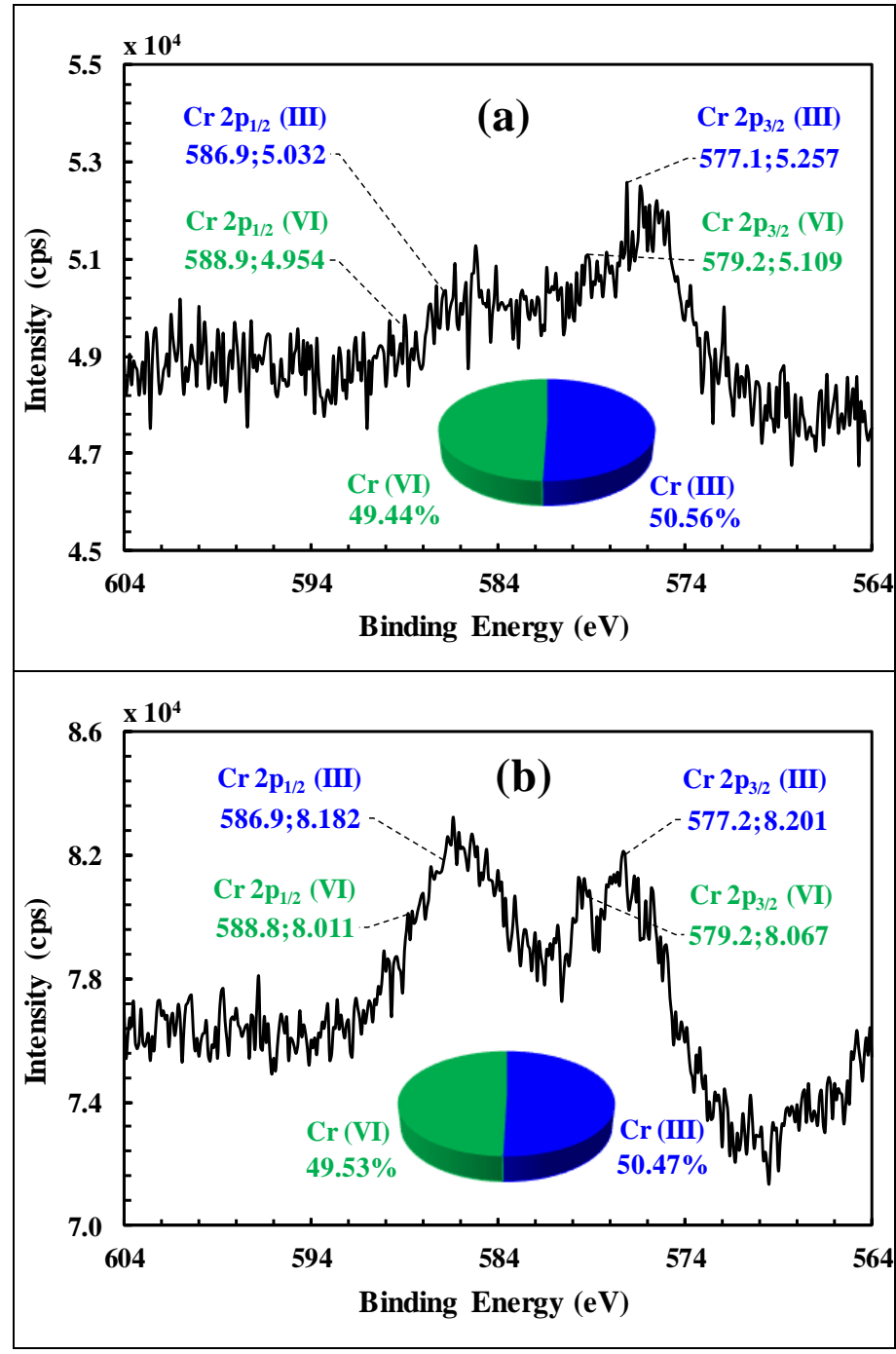

Figure 4 Narrow range XPS analysis of FS (a) and EAFD (b)

As seen in Figure 4-(a), for FS, consistent with the literature studies, trivalent chromium was assigned at $577.1 \mathrm{eV}$ with the peak intensity of $5.257 \times 10^{4}$ cps while hexavalent form corresponded to $579.2 \mathrm{eV}$ with $5.109 \times 10^{4} \mathrm{cps}$ for $2 \mathrm{p}_{3 / 2}$ orbitals. On the other hand, lower intensity peaks were obtained for $2 \mathrm{p}_{1 / 2}$ 
orbitals. Specifically, trivalent and hexavalent oxidation states were sequentially determined at 586.9 and $588.9 \mathrm{eV}$ with the respective intensities of $5.032 \times 10^{4}$ and $4.954 \times 10^{4}$ cps. By comparing the intensities of the peaks examined, the relative proportions of $\mathrm{Cr}$ (III) and $\mathrm{Cr}$ (VI) for FS were calculated as 50.56 and $49.44 \%$, respectively.

According to Figure 4-(b), almost the same binding energies with respect to FS were determined for EAFD sample. However, in this case, much higher peak intensities were observed for the corresponding orbitals and oxidation states. Specifically, for $2 \mathrm{p}_{3 / 2}$ orbitals, trivalent and hexavalent forms were assigned with $8.201 \times 10^{4}$ and $8.067 \times 10^{4} \mathrm{cps}$, respectively. For $2 \mathrm{p}_{1 / 2}$ orbitals, the intensity values of $8.182 \times 10^{4}$ and $8.011 \times 10^{4} \mathrm{cps}$ were obtained for the respective trivalent and hexavalent chromium. Accordingly, the relative proportions of $\mathrm{Cr}$ (III) and $\mathrm{Cr}$ (VI) for EAFD were calculated as 50.47 and $49.53 \%$, respectively. In other words, almost half of the total chromium content for both FS and EAFD are present as hazardous hexavalent forms.

\subsection{The Results of Leaching Tests}

The leachability characteristics of eight heavy metals from FS and EAFD are given in Table 4.

Table 4 Leachability characteristics of heavy metals

\begin{tabular}{|c|c|c|c|c|c|}
\hline \multirow{2}{*}{ 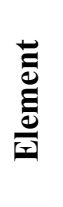 } & \multicolumn{2}{|c|}{ Solubility (mg/l) } & \multicolumn{3}{|c|}{$\begin{array}{c}\text { Toxicity limits (mg/l) } \\
\text { (Appendix 11-A) } \\
\text { (Acar and Atalay, 2013) }\end{array}$} \\
\hline & FS & EAFD & $I^{a}$ & NHW $^{b}$ & $H_{W}{ }^{c}$ \\
\hline$C d$ & 0.00003 & 0.00023 & $\leq 0.004$ & $\begin{array}{c}0.004- \\
0.1\end{array}$ & $<0.1-0.5$ \\
\hline Co & 0.00072 & 0.00005 & $\mathrm{NI}^{\mathrm{d}}$ & $\mathrm{NI}^{\mathrm{d}}$ & $\mathrm{NI}^{\mathrm{d}}$ \\
\hline $\mathrm{Cr}$ & 0.862 & 268.050 & $\leq 0.05$ & $0.05-1$ & $<1-7$ \\
\hline$C u$ & 0.0025 & 0.0037 & $\leq 0.2$ & $0.2-5$ & $<5-10$ \\
\hline$N i$ & 0.0154 & 0.00076 & $\leq 0.04$ & $0.04-1$ & $<1-4$ \\
\hline $\mathrm{Pb}$ & 0.00090 & 0.0056 & $\leq 0.05$ & $0.05-1$ & $<1-5$ \\
\hline$Z n$ & 0.0191 & 0.162 & $\leq 0.4$ & $0.4-5$ & $<5-20$ \\
\hline$M n$ & 0.028 & 0.0021 & $\mathrm{NI}^{\mathrm{d}}$ & $\mathrm{NI}^{\mathrm{d}}$ & $\mathrm{NI}^{\mathrm{d}}$ \\
\hline
\end{tabular}

a Inert waste.

${ }^{\mathrm{b}}$ Non-hazardous waste.

${ }^{\mathrm{c}}$ Hazardous waste.

d Not included.

According to Table 4, both FS and EAFD are far from being considered as hazardous waste in terms of the leaching capacities of all the metals examined except $\mathrm{Cr}$. In addition, their solubilities are even below the toxicity limits for non-hazardous waste. In particular, solubilities of chromium were determined as 0.862 and $268.050 \mathrm{mg} / 1$ for FS and EAFD, respectively. In other words, chromium solubility of EAFD is more than 300 times higher than that of FS based on the TS EN 12457-4 leaching test. This result cannot be explained by only the chromium contents of FS and EAFD, which are 3.11 and $15.44 \%$, respectively. In fact, it can be attributed to the spinel phase of FS where most of the chromium is immobilized. This results in a slight chromium release from FS (Panda et al., 2013). On the other hand, chromium is easly leached from the weakly crystalline magnesium dichromium oxide phase of EAFD. Therefore, EAFD can be regarded as a highly hazardous e-ISSN: 2148-2683 waste while FS is within the limit of non-hazardous waste according to the toxicity limits (Bulut et al., 2009; Fernández Pereira et al., 2009; Panda et al., 2013).

\section{Conclusions and Recommendations}

Overall results have shown that although the ferrochromium slag and the electric-arc furnace dust examined have similar $\mathrm{Cr}(\mathrm{III}) / \mathrm{Cr}$ (VI) ratio, mainly weak crystallinity makes the dust sample a highly hazardous waste while the slag sample can be considered as a non-hazardous waste due to its strong chromium bearing spinel phase. Therefore, hazardous hexavalent chromium must be reduced to much less dangerous immobile trivalent forms for the dust sample prior to disposed in landfills.

\section{Acknowledge}

The technical supports by East Anatolia High Technology Application and Research Center (DAYTAM) and ETI KROM INC. are gratefully acknowledged.

\section{References}

Acar, İ. (2020). Sintering properties of olivine and its utilization potential as a refractory raw material: Mineralogical and microstructural investigations. Ceramics International, 46(18, Part A), 28025-28034.

Acar, I., Atalay, M. U. (2013). Characterization of sintered class F fly ashes. Fuel, 106, 195-203.

Aigbe, U. O., Osibote, O. A. (2020). A review of hexavalent chromium removal from aqueous solutions by sorption technique using nanomaterials. Journal of Environmental Chemical Engineering, 8(6), 104503.

Arnold, M. C., de Vargas, A. S., Bianchini, L. (2017). Study of electric-arc furnace dust (EAFD) in fly ash and rice husk ashbased geopolymers. Advanced Powder Technology, 28(9), 2023-2034.

Bulut, U., Ozverdi, A., Erdem, M. (2009). Leaching behavior of pollutants in ferrochrome arc furnace dust and its stabilization/solidification using ferrous sulphate and Portland cement. Journal of Hazardous Materials, 162(2-3), 893-898.

Chagas, P. M. B., Caetano, A. A., Tireli, A. A., Cesar, P. H. S., Corrêa, A. D., Guimarães, I. D. R. (2019). Use of an Environmental Pollutant From Hexavalent Chromium Removal as a Green Catalyst in The Fenton Process. Scientific Reports, 9(1).

Cholake, S. T., Farzana, R., Numata, T., Sahajwalla, V. (2018). Transforming electric arc furnace waste into value added building products. Journal of Cleaner Production, 171, 11281139.

Dhal, B., Thatoi, H. N., Das, N. N., Pandey, B. D. (2013). Chemical and microbial remediation of hexavalent chromium from contaminated soil and mining/metallurgical solid waste: A review. Journal of Hazardous Materials, 250-251, 272291.

Erdem, M., Altundoğan, H. S., Turan, M. D., Tümen, F. (2005). Hexavalent chromium removal by ferrochromium slag. Journal of Hazardous Materials, 126(1-3), 176-182.

Erdoğan, S. T. (2011). Öğütülmüş Ferrokrom Cürufu Kullanılarak Jeopolimer Üretimi. Paper presented at the 9th National Congress on Concrete, İzmir. 
Fares, A. I., Sohel, K., Al-Jabri, K., Al-Mamun, A. (2021). Characteristics of ferrochrome slag aggregate and its uses as a green material in concrete - A review. Construction and Building Materials, 294, 123552.

Fernández Pereira, C., Luna, Y., Querol, X., Antenucci, D., Vale, J. (2009). Waste stabilization/solidification of an electric arc furnace dust using fly ash-based geopolymers. Fuel, 88(7), 1185-1193.

Gencel, O., Sutcu, M., Erdogmus, E., Koc, V., Cay, V. V., Gok, M. S. (2013). Properties of bricks with waste ferrochromium slag and zeolite. Journal of Cleaner Production, 59, 111-119.

Greunz, T., Steinberger, R., Strauß, B., Stifter, D. (2018). Reduction of hexavalent chromium embedded in organic insulation and corrosion inhibition layers during X-ray photoelectron spectroscopy (XPS) measurements. Corrosion Science, 143, 39-45.

Jena, S., Panigrahi, R. (2021). Feasibility study of the properties of geopolymer concrete with ferrochrome slag and silica fume. Materials Today: Proceedings, 38, 2476-2480.

Kumar B, C., Yaragal, S. C., Das, B. B. (2020). Ferrochrome ash - Its usage potential in alkali activated slag mortars. Journal of Cleaner Production, 257, 120577.

Mishra, J., Kumar Das, S., Krishna, R. S., Nanda, B., Kumar Patro, S., Mohammed Mustakim, S. (2020). Synthesis and characterization of a new class of geopolymer binder utilizing ferrochrome ash (FCA) for sustainable industrial waste management. Materials Today: Proceedings, 33, 5001-5006.

Murphy, V., Tofail, S. A. M., Hughes, H., McLoughlin, P. (2009). A novel study of hexavalent chromium detoxification by selected seaweed species using SEM-EDX and XPS analysis. Chemical Engineering Journal, 148(2-3), 425-433.

Nath, S. K. (2018). Geopolymerization behavior of ferrochrome slag and fly ash blends. Construction and Building Materials, 181, 487-494.

Panda, C. R., Mishra, K. K., Panda, K. C., Nayak, B. D., Nayak, B. B. (2013). Environmental and technical assessment of ferrochrome slag as concrete aggregate material. Construction and Building Materials, 49, 262-271.

Sekhar Biswal, S., Panda, C., Sahoo, S., Jena, T., Chandra Panda, K. (2021). Assessment of factors influencing the elution of chromium from ferrochromium slag using factorial design of experiment. Materials Today: Proceedings, 35, 97-101.

Shahid, M., Shamshad, S., Rafiq, M., Khalid, S., Bibi, I., Niazi, N. K., Dumat, C., Rashid, M. I. (2017). Chromium speciation, bioavailability, uptake, toxicity and detoxification in soilplant system: A review. Chemosphere, 178, 513-533. 